\title{
Determinan Cakupan Imunisasi Dasar Lengkap pada Penerima Program Keluarga Harapan
}

\section{Determinants of Complete Basic Immunization Coverage for Beneficiaries of Family Hope Program}

\author{
Wulansari $^{1}$, Mardiati Nadjib ${ }^{2}$ \\ ${ }^{1}$ Pascasarjana IImu Kesehatan Masyarakat, Fakultas Kesehatan Masyarakat, Universitas Indonesia \\ ${ }^{2}$ Departemen Administrasi dan Kebijakan Kesehatan, Fakultas Kesehatan Masyarakat, Universitas Indonesia \\ Korespondensi: Wulansari \\ e-mail:wulansari.pandes@gmail.com
}

\begin{abstract}
Abstrak
Kemiskinan merupakan permasalahan sosial bersifat multidimensi dan berhubungan dengan permasalahan kesehatan, pendidikan dan kesejahteraan sosial lainnya. Cakupan Imunisasi Dasar Lengkap (IDL) secara nasional mencapai 57,9\%, 32,9\% tidak lengkap dan sebanyak 9,2\% tidak diimunisasi, sementara indikator cakupan secara nasional minimal 90\% Penelitian ini bertujuan untuk mengetahui determinan apakah yang mempengaruhi cakupan imunisasi dasar lengkap pada bayi penerima Program Keluarga Harapan (PKH). Desain studi yang digunakan adalah cross sectional. Lokasi penelitian berada di 34 provinsi. Jumlah populasi sebanyak 9.205 responden dengan menggunakan data sekunder Survei Sosial Ekonomi Nasional (Susenas) tahun 2017. Hasil penelitian menunjukkan capaian imunisasi dasar lengkap sebesar 97,34\% dan 2,66\% tidak lengkap. Hasil penelitian menunjukkan variebel umur dan status perkawinan berhubungan positif serta berpengaruh secara signifikan, Variabel pendidikan dan pekerjaan berhubungan secara signifikan namun berhubungan negatif dalam cakupan imunisasi dasar. PKH telah memberikan kesempatan dan akses kepada rumah tangga miskin untuk melaksanakan program imunisasi dasar lengkap. Oleh karena itu diperlukannya penguatan supervisi terhadap ibu muda, ibu dengan status cerai, serta ibu yang bekerja guna meningkatkan pengetahuan, membangun kesadaran, menjaga serta memperkuat perubahan perilaku terkait, pengasuhan dan kesehatan untuk meningkatkan cakupan imunisasi dasar pada bayi.

Kata kunci : Program keluarga harapan, bantuan tunai bersyarat, imunisasi dasar
\end{abstract}

\begin{abstract}
Poverty is a multidimensional social problem and related to the problems of health, education and other social welfare. National Basic Immunization Coverage (IDL) reached 57.9\%, with 32.9\% was incomplete and $9.2 \%$ were not immunized, while national coverage indicators were at least $90 \%$. This study aims to determine the determinants that affects basic complete immunization coverage for babies receiving the Family Hope Program (PKH). The study design used was cross sectional. The research was located in 34 provinces. The total population is 9,205 respondents using secondary data from the National Socio-Economic Survey (Susenas) in 2017. The research shows that the achievement of complete basic immunization is $97.34 \%$ and $2.66 \%$ is incomplete. The results shows that age and marital status are positively related and significantly influence the basic immunization coverage, while education and employment variables are significantly associated but negatively related to basic immunization coverage. PKH has provided opportunities and access to poor households in implementing a complete basic immunization program. So it is necessary to intensify the supervision of young mothers, divorced mothers and working mothers to boost knowledge, build awareness, maintain and strengthen related behavioral changes, health and care to increase the coverage of basic immunization in infants.
\end{abstract}

Keyword: Family hope program, conditional cash tranfer, immunization

\section{Pendahuluan}

Jumlah penduduk miskin di Indonesia pada bulan September 2017 sebesar 26,58 juta orang (10,12\%). Penduduk miskin adalah penduduk dengan pengeluaran per kapita per bulan di bawah Garis Kemiskinan (BPS, 2018). Kemiskinan merupakan masalah global dan menjadi ancaman keberlangsungan bangsa di dunia. Kemiskinan merupakan permasalahan sosial yang bersifat multidimensi dan identik dengan permasalahan kesehatan, pendidikan dan kesejahteraan sosial lainnya. Penanggulangan kemiskinan merupa- kan komponen pertama dalam target Sustainable Development Goals (SDG) dengan menekankan pada hak azasi manusia agar diskriminasi tidak terjadi. Salah satu program penanggulangan kemiskinan di Indonesia yang sudah berjalan adalah bantuan langsung tunai bersyarat (conditional cash transfer) Program Keluarga Harapan (PKH). Program ini diharapkan dapat meningkatkan akses keluarga miskin dan rentan terhadap komponen kesehatan, pendidikan, dan kesejahteraan sosial (Kemensos, 2018). 
Bayi merupakan salah satu kelompok rentan yang belum dapat mandiri dalam memenuhi kebutuhan dasar dan pengambilan keputusan dan termasuk dalam kelompok inklusif (Kemenkumham, 2016). Perhatian utama terhadap kesehatan anak merupakan salah satu target SDG yakni mengakhiri kematian bayi dan balita yang dapat dicegah, dengan menurunkan angka kematian neonatal hingga 12 per 1.000 kelahiran hidup dan angka kematian balita 25 per 1.000 kelahiran hidup.

Kejadian kematian anak berusia bawah lima tahun (balita) pada negara berpenghasilan rendah dan menengah diperkirakan meningkat. Kematian anak disebabkan oleh banyak faktor, salah satunya daya tahan tubuh anak yang belum sempurna. Di Tiongkok jumlah kematian balita antara tahun 1996 sampai dengan tahun 2015 adalah 181.600 balita dan sebanyak 93.400 balita (51\%) kematian terjadi pada neonatus. Penyebab utama kematian balita disebabkan oleh kelainan bawaan, komplikasi kelahiran prematur, cedera, dan pneumonia (He et al., 2017)

Pada tahun 2013, di negara Afrika sub-Sahara ditemukan bahwa pneumonia diare dan campak merupakan penyebab setengah dari kematian anak. Penyebab lainnya yaitu kelainan bawaan, prematur, sepsis neonatal cidera dan penyebab lainnya, tren ini diperkirakan akan meningkat hingga tahun 2030 pada anak balita (Liu et al., 2015)

Kemajuan ilmu pengetahuan dan teknologi di bidang kesehatan menghasilkan berbagai penemuan, salah satunya adalah vaksin yang diimplementasikan melalui program imunisasi. Imunisasi adalah suatu upaya untuk menimbulkan/ meningkatkan kekebalan seseorang secara aktif terhadap suatu penyakit sehingga bila suatu saat terpajan dengan penyakit tersebut tidak akan sakit atau hanya mengalami sakit ringan (Kemenkes, 2017). Imunisasi telah terbukti dapat mencegah dan mengurangi kejadian sakit, cacat, dan kematian akibat PD3I (Penyakit Yang Dapat Dicegah Dengan Imunisasi) yang diperkirakan 2 hingga 3 juta kematian tiap tahunnya. Cakupan imunisasi campak di Indonesia adalah sebesar $84 \%$ dan merupakan negara dalam kategori sedang (Kemenkes, 2016).

Data Riset Kesehatan Dasar tahun 2018 menunjukkan cakupan Imunisasi Dasar Lengkap (IDL) mencapai 57,9\%, imunisasi tidak lengkap sebesar 32,9\% dan 9,2\% tidak diimunisasi (Kemenkes 2018). Campak merupakan 10 penyakit terbesar penyebab kematian anak usia 29 hari-4 tahun berdasarkan Riskesdas tahun 2007. Cakupan imunisasi campak mengalami kecenderungan penurunan selama periode 2013 (97,8\%), 2015 (92,3\%), namun kejadian Kejadian Luar Biasa (KLB) campak menunjukkan hal sebaliknya, yakni terjadi penurunan pada tahun $2013(862$ kasus) dan 2015 (831 kasus). Fenomena tersebut menunjukkan adanya hubungan negatif antara cakupan imunisasi campak dengan jumlah kasus campak (Kemenkes, 2016). Oleh karena itu perlu dilakukan analisa determinan sosial demografi terhadap cakupan imunisasi dasar lengkap guna mengetahui faktor-faktor yang mempengaruhi cakupan imunisasi dasar lengkap pada bayi. Jumlah kasus baru BTA+ pada anak usia 0-14 tahun cenderung menurun sesuai dengan cakupan imunisasi BCG yang konstan mengarah ke tinggi yakni antara 90\% - 100\%. Jawa timur merupakan provinsi dengan kasus tertinggi kejadian difteri dan mengalami kecenderungan meningkat sejak tahun 2012 sampai dengan 2015 yaitu mencapai 63\%, meskipun cakupan DPT3 mengalami kondisi konstan yang cukup tinggi yaitu antara 90\% - 100\%.

Cakupan imunisasi Hepatitis B menunjukkan proporsi sebesar 90\% selama tahun 2006 - 2016, namun prevalensi Hepatitis pada semua tipe pada tahun 2013 meningkat hampir 2 kali lipat dibanding tahun 2007. Prevalensi Hepatitis tertinggi berada pada kelompok kuintil indeks kepemilikan terbawah (Kemenkes, 2016). Hal tersebut menunjukkan adanya korelasi antara cakupan imunisasi dengan kejadian PD3I. Berdasarkan hal tersebut, pada tahun 2017 melalui peraturan pemerintah nomor 12 imunisasi dijadikan sebagai program wajib yang dibebankan kepada seseorang sebagai bagian masyarakat dalam melindungi dari penyakit yang dapat dicegah dengan imunisasi.

Ibu berusia tua (35-49 tahun) memiliki kemungkinan lebih besar untuk memberikan imunisasi dasar lengkap dibandingkan ibu yang muda (15-34 tahun) dan ditemukan adanya hubungan bermakna antara umur ibu yang lebih tua dengan status imunisasi anak (Febri 2012). Status perkawinan memiliki kemungkinan berpengaruh dalam mencapai imunisasi dasar lengkap pada bayi, dimana dukungan suami berpengaruh secara signifikan terhadap kepatuhan ibu dalam mengimunisasi anak usia sekolah (Wati 2015).

Pendidikan diketahui berpengaruh secara signifikan terhadap cakupan imunisasi dasar 
lengkap. Ibu bayi dengan pendidikan tinggi memiliki kemungkinan lebih besar untuk memberikan imunisasi dasar lengkap dibandingkan ibu berpendiidkan rendah (Arifin dan Prasasti 2017). Wilayah diduga berpengaruh terhadap cakupan imunisasi dasar lengkap. Cakupan imunisasi dasar lengkap lebih banyak ditemukan di kota dibandingkan dengan di desa menurut penelitian oleh Ardiyanto (2017) dan (Pratiwi 2010). Internet memiliki hubungan positif dalam perubahan pengetahuan, dukungan sosial, perilaku kesehatan, peningkatan klinis dan keyakinan tentang kemampuan individu dalam melakukan tugas/tindakan tertentu (Bennett and Glasgow 2009). Berdasarkan hal tersebut ada kesenjangan berkaitan yang dengan faktor-faktor terkait cakupan imunisasi seperti umur, tingkat pendidikan dan wilayah. Oleh karena itu penelitian ini dilakukan untuk mengetahui apakah terdapat hubungan antara determinan sosial demografi dengan cakupan imunisasi dasar lengkap pada bayi penerima PKH di 34 provinsi tahun 2017 serta apakah PKH dapat meningkatkan akses layanan imunisasi dan perubahan perilaku kesehatan pada keluarga miskin.

\section{Metode Penelitian}

Penelitian ini menggunakan desain studi cross sectional (potong lintang) dengan menggunakan banyak observasi studi pada satu waktu. Objek penelitian adalah ibu dan bayi sebagai Keluarga Penerima Manfaat (KPM) pada Program Keluarga Harapan (PKH) berjumlah 9.205 responden. Lokasi penelitian berada di 34 provinsi dengan menggunakan data sekunder yakni Survei Sosial Ekonomi Nasional (Susenas) tahun 2017.

Jenis data yang dikumpulkan adalah determinan sosial-demografi sebagai karakteristik ibu yang mempengaruhi cakupan imunisasi dasar secara lengkap meliputi variabel umur ibu, status perkawinan, pendidikan, pekerjaan, wilayah dan akses internet. Analisa data menggunakan perangkat lunak STATA 15 dan dilakukan secara univariat, bivariat dan multivariat (regresi probit). Penggunaan model probit merupakan salah satu tipe regresi yang berfungsi untuk menganalisis hubungan antara satu variabel dependen dengan lebih dari satu variabel independen.

Variabel dependen pada model probit merupakan data kualitatif bersifat dikotomi yakni bernilai 1 menyatakan terdapat sebuah karakteristik dan bernilai 0 untuk menyatakan tidak terdapatnya sebuah karakteristik. Spesifikasi model ekonometrika yang digunakan dalam penelitian ini yakni sebagai berikut:

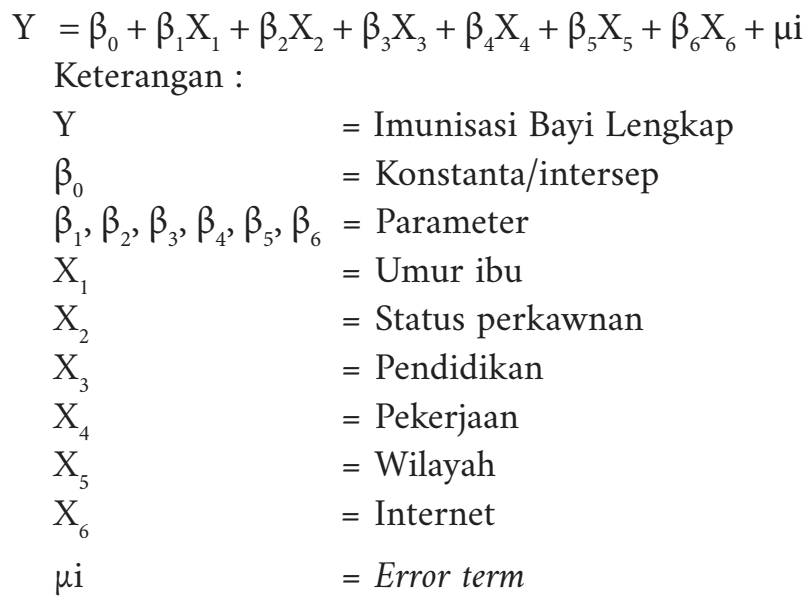

\section{Hasil Penelitian}

Karakteristik subjek penelitian adalah bayi berusia 0 sampai dengan 24 bulan yang telah menerima imunisasi dasar dan ibu bayi merupakan wanita subur berusia 15 sampai dengan 49 tahun penerima PKH.

\section{Analisis univariat}

Tabel 1. Distribusi Frekuensi Cakupan Imunisasi Dasar pada Penerima PKH Tahun 2017

\begin{tabular}{ccc}
\hline Cakupan IDL & N & \% \\
\hline Tidak lengkap & 245 & 2,66 \\
Lengkap & 8.960 & 97,34 \\
\hline Total & $\mathbf{9 . 2 0 5}$ & $\mathbf{1 0 0}$ \\
\hline
\end{tabular}

Tabel 2. Distribusi Frekuensi Determinan Cakupan IDL Pada Penerima PKH

\begin{tabular}{|c|c|c|}
\hline Variabel & $\mathbf{N}$ & $\%$ \\
\hline \multicolumn{3}{|l|}{ Umur } \\
\hline Muda (15-34 tahun) & 4.103 & 44,57 \\
\hline Tua (35-49 tahun) & 5.102 & 55,43 \\
\hline \multicolumn{3}{|l|}{ Status Perkawinan } \\
\hline Cerai & 237 & 2,57 \\
\hline Kawin & 8.968 & 97,43 \\
\hline \multicolumn{3}{|l|}{ Pendidikan } \\
\hline Rendah ( $\leq$ SMP sederajat) & 5.907 & 64,17 \\
\hline Tinggi ( $\geq$ SMA sederajat) & 3.298 & 35,83 \\
\hline \multicolumn{3}{|l|}{ Pekerjaan } \\
\hline $\begin{array}{l}\text { Tidak Bekerja } \\
\text { Bekerja }\end{array}$ & $\begin{array}{l}3.953 \\
5.252\end{array}$ & $\begin{array}{l}42,94 \\
57,06\end{array}$ \\
\hline $\begin{array}{l}\text { Wilayah } \\
\text { Desa } \\
\text { Kota }\end{array}$ & $\begin{array}{l}2.493 \\
6.712\end{array}$ & $\begin{array}{l}27,08 \\
72,92\end{array}$ \\
\hline \multicolumn{3}{|l|}{ Akses Internet } \\
\hline Tidak akses & 7.146 & 77,63 \\
\hline
\end{tabular}




\begin{tabular}{lcc}
\hline \hline Akses & 2.059 & 22,37 \\
\hline Total & $\mathbf{9 . 2 0 5}$ & $\mathbf{1 0 0}$ \\
\hline
\end{tabular}

Analisis univariat menghasilkan distribusi frekuensi dan persentase dari tiap variabel penelitian mengenai pemberian cakupan imunisasi pada bayi penerima PKH. Tabel 1 menunjukkan bahwa cakupan imunisasi dasar lengkap pada bayi penerima PKH yakni sebesar 97,34\% sedangkan yang tidak mencapai imunisasi lengkap mencapai hanya 2,66\%. Responden penelitian lebih banyak pada kelompok umur tua (35-49 tahun) dari pada kelompok umur muda (15-34 tahun) yaitu sebanyak 5,102 (55.43\%). Status perkawinan dengan status kawin lebih banyak daripada responden cerai yakni sebanyak 8,968 (97.43\%).

Pada kelompok status pendidikan, responden dengan tingkat pendidikan rendah lebih banyak daripada tingkat pendidikan tinggi yakni sebanyak 5,907 (64.17\%). Status pekerjaan responden lebih banyak bekerja yakni sebanyak 5,252 (57.06\%) daripada responden yang tidak bekerja. Responden lebih banyak tinggal di wilayah perkotaan yakni

sebanyak 6,712 (72.92 \%) daripada pedesaan. Responden yang tidak mengakses internet lebih banyak daripada yang mengakses internet yakni sebanyak 7,146 (77.63\%) (Tabel 2).

\section{Analisis Bivariat}

Analisa bivariat menggunakan chi square. Analisis bivariat menampilkan distribusi variansi dari variabel $Y$ dependen dengan masing-masing variabel independen (X). Analisis bivariat memperlihatkan hubungan antara variable independen dnegan variable dependen yang menggunakan uji kai kuadrat (Chi-Square). Berdasarkan tabel 3 di atas, dapat disimpulkan bahwa terdapat hubungan yang signifikan antara variabel umur $(0,000)$, status perkawinan $(0,000)$, tingkat pendidikan $(0,000)$, dan status pekerjaan $(0,006)$ dan akses internet $(0,000)$ terhadap cakupan imunisasi dasar lengkap dengan nilai $\mathrm{p}$ value $<0,005$. Hasil uji statistik menunjukkan nilai $p$-value sebesar 0,844 $(p$-value $<0,05)$ yang berarti variabel wilayah tidak berhubungan signifikan terhadap cakupan IDL.

Tabel 3 menunjukkan bahwa angka cakupan

Tabel 3. Uji Chi-Square Determinan Cakupan IDL

\begin{tabular}{|c|c|c|c|c|c|c|c|}
\hline \multirow{3}{*}{ Variabel } & \multicolumn{4}{|c|}{ Cakupan IDL } & \multirow{2}{*}{\multicolumn{2}{|c|}{ Total }} & \multirow{3}{*}{ Sig } \\
\hline & \multicolumn{2}{|c|}{ Tidak Lengkap } & \multicolumn{2}{|c|}{ Lengkap } & & & \\
\hline & $\mathbf{N}$ & $\%$ & $\mathbf{n}$ & $\%$ & $\mathbf{n}$ & $\%$ & \\
\hline \multicolumn{8}{|l|}{ Kelompok Umur } \\
\hline Muda (15-34 tahun) & 207 & 5,05 & 3.896 & 94,95 & 4.103 & 100 & \multirow[b]{2}{*}{$0,000^{\star}$} \\
\hline Tua (35-49 tahun) & 38 & 0,74 & 5.064 & 99,26 & 5.102 & 100 & \\
\hline \multicolumn{8}{|l|}{ Status Perkawinan } \\
\hline Cerai & 18 & 7,59 & 219 & 92,41 & 237 & 100 & \multirow{2}{*}{$0,000^{*}$} \\
\hline Kawin & 227 & 2,53 & 8.741 & 97,47 & 8.968 & 100 & \\
\hline \multicolumn{8}{|l|}{ Pendidikan } \\
\hline Rendah & 115 & 1,95 & 5.792 & 98,05 & 5.907 & 100 & \multirow{2}{*}{$0,000^{\star}$} \\
\hline Tinggi & 130 & 3,94 & 3.168 & 96,06 & 3.298 & 100 & \\
\hline \multicolumn{8}{|l|}{ Pekerjaan } \\
\hline Tidak bekerja & 84 & 2,12 & 3.869 & 97,88 & 3,953 & 100 & \multirow[b]{2}{*}{$0,006^{*}$} \\
\hline Bekerja & 161 & 3,07 & 5.091 & 96,93 & 5,252 & 100 & \\
\hline \multicolumn{8}{|l|}{ Wilayah } \\
\hline Desa & 65 & 2,61 & 2.428 & 97,39 & 2.493 & 100 & \multirow{2}{*}{0,844} \\
\hline Kota & 180 & 2,68 & 6.532 & 97,32 & 6.712 & 100 & \\
\hline \multicolumn{8}{|l|}{ Internet } \\
\hline Tidak Akses & 155 & 2,17 & 6.991 & 97,83 & 7.146 & 100 & \multirow{2}{*}{$0,000^{\star}$} \\
\hline Akses & 90 & 4,37 & 1.969 & 95,63 & 2.059 & 100 & \\
\hline
\end{tabular}

*bermakna signifikan secara statistik $(\mathrm{P}$ value $<0,05)$ 
Tabel 4. Analisis Probit Determinan Cakupan IDL

\begin{tabular}{lcccccc}
\hline \multicolumn{1}{c}{ Variabel } & Koefisien & Standar Eror & $\mathrm{z}$ & $\mathrm{P}>|\mathrm{z}|$ & [95\% Confidence & Interval] \\
\hline Umur & & & & & & \\
Tua & 0.7808467 & 0.069298 & 11.27 & 0.000 & 0.6450251 & 0.9166683 \\
$\begin{array}{l}\text { Status Kawin } \\
\text { Kawin }\end{array}$ & 0.4882161 & 0.1294747 & 3.77 & 0.000 & 0.2344503 & 0.7419819 \\
$\begin{array}{l}\text { Pendidikan } \\
\text { Tinggi }\end{array}$ & -0.2281369 & 0.0640059 & -3.56 & 0.000 & -0.3535861 & -0.1026877 \\
$\begin{array}{l}\text { Pekerjaan } \\
\text { Kerja }\end{array}$ & -0.1937902 & 0.06084 & -3.19 & 0.001 & -0.3130343 & -0.0745461 \\
$\begin{array}{l}\text { Wilayah } \\
\text { Kota }\end{array}$ & -0.0677561 & 0.0690934 & -0.98 & 0.327 & -0.2031767 & 0.0676645 \\
$\begin{array}{l}\text { Internet } \\
\text { Akses }\end{array}$ & -0.0728568 & 0.0699211 & -1.04 & 0.297 & -0.2098997 & 0.0641861 \\
\hline
\end{tabular}

IDL pada bayi dari kelompok umur ibu tua (35 s.d 49 tahun) lebih tinggi (99,26\%) dibandingkan dengan bayi pada umur ibu muda (94,95\%). Angka cakupan IDL pada kelompok ibu dengan status kawin lebih tinggi (97.47\%) dibandingkan dengan status cerai (92.41\%). Angka IDL pada pendidikan ibu rendah ( $\leq$ SMP sederajat) lebih tinggi $(98,05 \%)$ dibandingkan dengan pendidikan ibu tinggi ( $\geq$ SMA sederajat) (96,06\%). Angka IDL pada status ibu tidak bekerja lebih tinggi (97,88\%) dibandingkan ibu bekerja (96,93\%). Angka IDL pada ibu yang tidak memiliki akses internet lebih tinggi (97,83\%) dibandingkan ibu yang memiliki akses internet $(95,63)$. Angka IDL pada wilayah pedesaan lebih tinggi $(97,39 \%)$ dibandingkan wilayah perkotaan $(97,32)$.

Hasil pengolahan uji asumsi probit didapatkan model:

$\overline{\mathrm{y}}=0,6848+0,7808$ umur $+0,4882$ status perkawinan $-0,2281$ pendidikan $-0,1937$ pekerjaan - 0,0677wilayah - 0,0728internet

Berdasarkan tabel 4, diketahui bahwa variabel yang signifikan terhadap IDL adalah umur, status perkawinan, tingkat pendidikan dan status kerja. Hasil uji regresi probit dari persamaan di atas menunjukkan bahwa :

a. Ibu yang berumur tua (35-49 tahun) berpeluang meningkatkan cakupan imunisasi dasar lengkap sebesar 0,780 kali lebih tinggi dibandingkan umur ibu muda b. Status kawin berpeluang meningkatkan cakupan imunisasi dasar lengkap sebesar 0,49 kali lebih tinggi dibandingkan status cerai

c. Pendidikan tinggi berpeluang menurunkan cakupan imunisasi dasar lengkap sebesar 0,23 kali lebih tinggi dibandingkan dengan tingkat pendidikan rendah.

d. Status bekerja berpeluang menurunkan cakupan imunisasi dasar lengkap sebesar 0,19 kali lebih tinggi dibandingkan dengan tidak bekerja

e. Wilayah kota berpeluang menurunkan cakupan imunisasi dasar lengkap sebesar 0,07 kali lebih tinggi dibandingkan wilayah pedesaan

f. Akses terhadap internet berpeluang menurunkan cakupan imunisasi dasar lengkap sebesar 0,07 kali lebih tinggi dibandingkan ibu yang tidak mengakses internet

\section{Pembahasan}

Hasil penelitian menunjukkan variabel yang secara signifikan mempengaruhi cakupan imunisasi dasar lengkap (IDL) adalah umur, status perkawinan, pendidikan dan pekerjaan.

\section{Umur}

Ibu dengan usia tua (35-49 tahun) memiliki kemungkinan lebih besar untuk memberikan imunisasi dasar lengkap kepada bayi dibandingkan ibu yang muda (15-34 tahun). Hal ini sejalan dengan penelitian Febri (2012) yang membuktikan adanya hubungan bermakna antara umur ibu dengan status imunisasi anak. Ibu yang berusia lebih tua memiliki pengalaman lebih banyak dan ibu lebih 
mengerti akan bahaya ancaman penyakit sehingga mereka melakukan tindakan pencegahan penyakit. Sedikitnya peluang ibu berusia muda disebabkan karena belum banyak terpajan dengan informasi kesehatan dan belum memahami manfaat imunisasi pada anaknya (Wati, 2015).

\section{Status Perkawinan}

Status perkawinan memiliki kemungkinan berpengaruh lebih besar secara signifikan $(P=0,000)$ dalam mencapai IDL pada bayi. Cakupan IDL ditemukan lebih banyak pada anak dari ibu dengan status kawin dibandingkan dengan ibu berstatus cerai. Hal ini sejalan dengan penelitian Wati (2015) yakni dukungan suami berpengaruh secara signifikan terhadap kepatuhan ibu dalam melakukan imunisasi anak usia sekolah. Pernikahan bertujuan untuk membentuk keluarga atau rumah tangga yang bahagia dan kekal berdasarkan Ketuhanan Yang Maha Esa. Berdasarkan undang-undang perkawinan orang tua wajib untuk memelihara dan mendidik anak-anak sebaik mungkin. Hal ini menunjukkan bahwa terjadi pembagian tanggungjawab serta pendampingan suami dan istri dalam penyelesaian permasalahan dan pengasuhan anak (Putri, 2015).

\section{Pendidikan}

Pendidikan ibu mempunyai kemungkinan berpengaruh lebih besar secara signifikan dalam capaian IDL pada bayinya. Hal ini sejalan dengan penelitian Thaib, et al (2014) bahwa terdapat hubungan bermakna antara kelengkapan imunisasi dasar bayi dengan pendidikan ibu $(\mathrm{P}=0,001)$. Pada penelitian ini pendidikan secara signifikan berpengaruh terhadap cakupan IDL, namun berpeluang menurunkan cakupan imunisasi dasar lengkap jika dibanding bayi dari ibu berpendidikan rendah. Penelitian ini mengungkapkan fakta bahwa pendidikan tinggi justru memiliki efek negatif terhadap responden untuk menurunkan cakupan IDL dibandingkan dengan ibu berpendidikan rendah. Hal ini bertentangan dengan penelitian Arifin dan Prasasti (2017) yang mengatakan bahwa terdapat hubungan yang bermakna antara pendidikan ibu dengan cakupan imunisasi dasar lengkap. Pendidikan yang rendah memberikan efek yang negatif terhadap responden untuk mengimunisasi anaknya, sebaliknya pendidikan yang tinggi memberikan efek yang positif terhadap responden untuk mengimunisasi anaknya sampai lengkap.

Pendidikan mempengaruhi pengetahuan dan proses belajar, makin tinggi pendidikan seseorang makin mudah untuk menerima informasi. Maka di- harapkan seseorang dengan pendidikan tinggi, orang tersebut akan semakin luas pula pengetahuannya (Notoatmojo, 2007). Pendidikan tinggi tidak menjamin bahwa seseorang akan mau dan mampu mengakses pelayanan kesehatan. Sebuah penelitian di negara berkembang menunjukkan bahwa intervensi perawatan kesehatan yang efektif kurang dimanfaatkan karena faktor pendidikan merupakan salah satu yang dapat membuat bias persepsi mengenai penyakit dan potensi manfaat perawatan kesehatan. Pendidikan memiliki hubungan ketergantungan dengan norma-norma sosial yang berlaku secara mutlak yang dipengaruhi oleh lingkungan sosial ekonomi (Donnell, 2007). Hal ini memungkinkan terjadinya sikap negatif terhadap pelaksanaan imunisasi meskipun pada responden berpendidikan tinggi dikarenakan masih kentalnya norma sosial yang mempengaruhi pola pikir dan sikap, yang mana sikap dan peran gender merupakan faktor penting dalam penentu perilaku pencarian kesehatan.

Sikap merupakan respon tertutup terhadap stimulus atau objek, belum merupakan tindakan/aktivitas, tetapi dapat menjadi predisposisi suatu perilaku. Pertimbangan kenyamanan saat anak diimunisasi, kenyamanan ibu setelah anak diimunisasi, efek, pandangan agama (halal/haram) turut mempengaruhi sikap ibu dalam mengimunisasi bayinya (Triana, 2016). Agar sikap dapat menjadi suatu perbuatan nyata perlu didukung oleh faktor pendukung berupa fasilitas dan dukungan lingkungan sekitar (Efendi, 2009). Peningkatan pemanfaatan layanan kesehatan di negara berkembang dilakukan melalui peningkatan kepercayaan melalui pengamatan keefektifan layanan sebab efek imunisasi tidak dapat dilihat secara langsung sehingga diperlukan intervensi berkaitan dengan konsep penyakit (Donnell, 2007). Pendampingan pada ibu dengan pendidikan rendah maupun tinggi perlu dilakukan lebih intens, guna memastikan bahwa semua syarat/protokol dapat dipenuhi.

Peran pendamping PKH memfasilitasi akses kepada layanan pendidikan, kesehatan dan kesejahteraan sosial juga terhadap pemenuhan komitmen dan kewajiban kehadiran pada layanan fasilitas pendidikan dan kesehatan. Pendamping PKH melakukan perannya sebagai fasilitator, pendidik, representasi/ perwakilan masyarakat, serta teknis (Rahmawati, 2017). Pertemuan Peningkatan Kemampuan Keluarga (P2K2) yang diselenggarakan secara rutin setiap bulannya dilaksanakan dengan harapan Keluarga 
Penerima Manfaat (KPM) terpapar dengan pengetahuan tentang kesehatan. Kegiatan tersebut sekaligus melakukan pengawasan dan evaluasi terhadap target program berupa cakupan IDL bayi agar dapat tercapai sesuai program nasional.

\section{Status Pekerjaan}

Variabel status pekerjaan ibu berpengaruh secara signifikan $(\mathrm{P}=0,001)$, tetapi menurunkan peluang terhadap cakupan imunisasi dasar lengkap. Hal ini tidak sejalan dengan penelitian (Pratiwi 2010) bahwa tidak terdapat hubungan bermakna antara variabel pekerjaan ibu dengan status IDL. Bayi dari ibu yang bekerja memiliki kemungkinan lebih besar untuk menurunkan cakupan imunisasi dasar lengkap dibandingkan bayi dari ibu yang tidak bekerja. Hal ini menunjukkan bahwa pekerjaan termasuk salah satu faktor yang cukup berpengaruh terhadap cakupan IDL menurut (Prihanti 2016) dan (Machsun dan Susanti 2018).

Ibu yang bekerja tidak memiliki cukup banyak waktu dalam pengasuhan dan interaksi dengan bayi, sedangkan ibu yang tidak bekerja memiliki kesempatan yang lebih banyak dalam mengakses pelayanan kesehatan. Ibu yang tidak bekerja memiliki kesempatan yang lebih besar untuk membawa anaknya datang ke pelayanan posyandu untuk melakukan imunisasi dibandingkan ibu yang bekerja (Machsun dan Susanti, 2018). Lupa terhadap jadwal imunisasi bayi dikarenakan kesibukan pekerjaan merupakan salah satu alasan rendahnya cakupan imunisasi dasar lengkap pada ibu bekerja dibandingkan dengan ibu yang tidak bekerja menurut (Notoatmodjo, 2003).

\section{Wilayah Tempat tinggal}

Daerah/wilayah tinggal tidak berpengaruh secara signifikan $(\mathrm{P}=0,327)$ terhadap cakupan imunisasi dasar lengkap. Hal ini bertentangan dengan hasil penelitian yang dilakukan oleh (Pratiwi 2010), dimana wilayah/daerah diduga berpengaruh terhadap cakupan imunisasi dasar lengakap. Cakupan imunisasi dasar lengkap lebih banyak ditemukan di kota dibandingkan dengan di desa menurut penelitian oleh Ardiyanto (2017) dan (Pratiwi 2010).

Pada penelitian ini hal tersebut tidak terbukti, sehingga dapat dikatakan bahwa tidak ada perbedaan angka IDL antara pedesaan dan perkotaan. Program keluarga harapan merupakan sebagai salah satu bentuk perluasan cakupan jaminan sosial berupa bantuan sosial kepada keluarga-keluarga miskin, baik di pedesaan maupun di perkotaan (Nainggolan, 2012). Peserta PKH memiliki perlakuan dan prosedur yang sama dalam pelaksanaannya baik di kota maupun di desa. Tidak adanya perbedaan angka IDL di desa dan kota kemungkinan disebabkan karena pendamping sosial telah melaksanakan tugas sesuai dengan ketentuan, demikian pula pada penerima program PKH telah melaksanakan protokol program dengan baik.

\section{Akses terhadap Internet}

Internet dan media sosial berpeluang sangat besar dalam penyampaian informasi kesehatan. Pada beberapa penelitian RCT (Random Control Trial) untuk mengetahi efektivitas intervensi melalui internet sebagai kelompok kontrol pada penyakit kronis menunjukkan bahwa terdapat hubungan positif dalam perubahan pengetahuan, dukungan sosial, perilaku kesehatan, peningkatan klinis dan keyakinan tentang kemampuan individu dalam melakukan tugas/tindakan tertentu (Bennett and Glasgow 2009). Promosi dan program pendidikan kesehatan melalui pengiriman pesan melalui media sosial secara efektif dapat meningkatkan pengetahuan dan kepuasan belajar tentang diabetes mellitus tipe 2 (Ekadinata, 2017).

Bertentangan dengan penelitian ini menunjukkan bahwa tidak ada perbedaan angka imunisasi dasar lengkap berdasarkan akses internet $(P=0,297)$. Internet adalah interaksi antar jaringan komputer namun secara umum internet dipandang sebagai sumber daya informasi yang berisi database/perpustakaan multimedia yang dapat digunakan untuk bisnis, hiburan, olahraga, politik, dll (Sidharta, 1996). Internet secara luas digunakan oleh masyarakat dan dapat berfungsi sebagai salah satu upaya promosi kesehatan guna meningkatkan pengetahuan dan kesadaran masyarakat untuk hidup sehat.

Pada negara maju internet semakin berfungsi sebagai platform untuk pengiriman intervensi kesehatan masyarakat dan keberhasilan intervensi telah ditunjukkan di berbagai kondisi (Bennett and Glasgow, 2009). Tidak adanya perbedaan angka imunisasi dasar lengkap berdasarkan akses internet menunjukkan bahwa penggunaan intenet belum banyak digunakan dan dimanfaatkan sebagai salah satu media informasi oleh penerima PKH. Kemunginan disebabkan karena ketidakmampuan secara finansial dan akses (jarak, akomodasi) untuk membeli peralatan elektronik yang terhubung dengan internet serta kurangnya pengetahuan terhadap teknologi internet. 


\section{Kesimpulan dan Saran}

Berdasarkan hasil penelitian ini, variabel umur dan status perkawinan memiliki hubungan yang positif dan berpengaruh secara signifikan terhadap cakupan imunisasi dasar lengkap. Sementara variabel pendidikan dan pekerjaan berpengaruh secara signifikan namun memiliki hubungan yang negatif. Variabel akses internet dan wilayah tempat tinggal tidak berhubugan secara signifikan dalam cakupan IDL. Dari hasil penelitian ini penulis menyarakan untuk mengencarkan supervisi program $\mathrm{PKH}$ untuk meningkatkan cakupan imunisasi melalui pemberian kesempatan serta akses rumah tangga miskin untuk melaksanakan program imunisasi dasar lengkap. Kegiatan P2K2 dalam meningkatkan pengetahuan, membangun kesadaran, menjaga serta memperkuat perubahan perilaku terkait pendidikan, pengasuhan dan kesehatan harus dilakukan lebih masif. Terutama dalam mengedukasi ibu usia muda dengan status cerai dan ibu yang bekerja. Pada ibu yang bekerja, diperlukan pendekatan edukasi dan keterlibatan anggota keluarga lain yang dititipkan dalam pengasuhan anak. PKH dapat meningkatkan partisipasi keluarga miskin terhadap pelayanan kesehatan imunisasi, sehingga dapat mempertahankan status kesehatan anak dan meningkatkan status kesehatan keluarga. Dengan demikian PKH telah berhasil menjadi salah satu program jaminan sosial yang mampu meningkatkan akses layanan kesehatan.

\section{Daftar Pustaka}

Ardiyanto. 2017. Perbedaan Cakupan Imunisasi Polio Pada Bayi Antara Puskesmas Di Kota Desa Dan Di Kota Di Kabupaten Sukoharjo Periode Juli 2015 Sampai Dengan Juni 2016 [Skripsi]." Arifin dan Prasasti. 2017. Faktor Yang Berhubungan Dengan Kasus Difteri Anak Di Puskesmas Bangkalan Tahun 2016. Jurnal Berkala Epidemiologi FKM Universitas Airlangga. 5(1).

Badan Pusat Statistik. 2018. Berita Resmi Statistik Profil Kemiskinan Di Indonesia September 2017. January 2018.

Bennett, Gary G., and Russell E. Glasgow. 2009. The Delivery of Public Health Interventions via the Internet: Actualizing Their Potential. Annual Review of Public Health. 30 (1):273-92. Donnell, Owen O. 2007. Access to Health Care in Developing Countries: Breaking down Demand Side Barriers Acesso Aos Cuidados de Saúde
Nos Países Em Desenvolvimento : Rompendo Barreiras Contra a Demanda. 23 (12):2820-34. Efendi, Ferry., Makhfudi. 2009. Keperawatan Kesehatan Komunitas Teori Dan Praktik Dalam Keperawatan. Jakarta: Salemba Medika. Ekadinata, et al. 2017. Promosi Kesehatan Menggunakan GambarDanTeksDalam Aplikasi WhatsAppPadaKader Posbindu. Universitas Gajah Mada. 3 (1):1-15.

Febri, Ririn Rahmala. 2012. Faktor-Faktor Yang Berhubungan Dengan Pemberian Imunisasi Campak Pada Batita Di Wilayah Kerja Puskesmas Lareh Sago Halaban Kabupaten 50 Kota Tahun 2012. Fakultsas Kesehatan Masyarakat, Universitas Sumatera Utara, Medan. He, Chunhua, Li Liu, Yue Chu, Jamie Perin, Li Dai, Xiaohong Li, Lei Miao, et al. 2017. National and Subnational All-Cause and Cause-Specific Child Mortality in China, 1996-2015: A Systematic Analysis with Implications for the Sustainable Development Goals. The Lancet Global Health. 5 (2):e186-97. Kemenkes. 2017. Peraturan Menteri kesehatan Republik Indonesia Nomor 12 Tahun 2017 Tentang Penyelenggaraan Imunisasi, issued 2017.

Kemenkes. 2018. Hasil Utama Riskesdas 2018. Kementerian Kesehatan Republik Indonesia: Jakarta.

Kemenkes. 2016.InfoDatinStatusImunisasiDiIndonesia. Kementerian KesehatanRepublik Indonesia:Jakarta Kemenkumham. 2016. Laporan Akhir Kelompok Kerja Analisis Dan Evaluasi Hukum Dalam Rangka Melindungi Kelompok Rentan Fokus Kesejahteraan Anak. Kementerian Hukum dan Hak Asasi Manusia: Jakarta.

Kemensos. 2018. Program Keluarga Harapan. Nomor 1 tahun 2018, issued 2018. Kementerian Sosial Republik Indonesia: Jakarta. Liu, Li, Shefali Oza, Daniel Hogan, Jamie Perin, Igor Rudan, Joy E. Lawn, Simon Cousens, Colin Mathers, and Robert E. Black. 2015. Global, Regional, and National Causes of Child Mortality in 2000-13, With Projections to Inform Post-2015 Priorities: An Updated Systematic Analysis. The Lancet. 385 (9966).

Machsun dan Susanti. 2018. Analisa Faktor - Faktor Yang Berhubungan Dengan Status Imunisasi Dasar Lengkap Pada Bayi Di Desa Mangunrejo Kecamatan Ngadiluwih Kabupaten Kediri Tahun 2018. Preventia : The Indonesian Journal of Public Health. 3(2). Nainggolan, et al. 2012. Program Keluarga Harapan Di Indonesia: Dampak Pada Rumah Tangga Sangat Miskin Di Tujuh Provinsi. Edited by Junaeman. P3KS Press (Anggota IKAPI). Notoatmodjo. 2003. Pendidikan Dan Per- 
ilaku Kesehatan. Jakarta: Rineka Cipta. sis]. Universitas Muhammadiyah Surakarta. Peraturan Presiden Republik Indonesia No- Rahmawati, et al. 2017. Peran Pendampmor 15 Tahun 2010. 2010. Percepatan Pen- ing Dalam Pemberdayaan Masyarakat Mianggulangan Kemiskinan. Vol. 22. Indonesia. skin Melalui Program Keluarga Harapan, PenPratiwi, Luriana Nur. 2010. Faktor-Faktor didikan Luar Sekolah. Journal of Nonformal Yang Berhubungan Dengan Status Imunisa- Education and Community Empowerment. si Dasar Pada Balita Umur 12-23 Bulan Di In- Sidharta,Lani. 1996. Internet Informasi Bebas Hambatan donesia Tahun 2010 (Analisis Data Riset Kes- $\quad$ 1. Edisi kedua Jakarta: Elex Media Komputindo. ehatan Dasar 2010). Universitas Indonesia. Triana, Vivi. 2016. Faktor Yang BerhubunPrihanti, et al. 2016. Faktor-Faktor Yang Me- gan Dengan Pemberian Imunisasi Dasar Lengmepengarhi Status Kelengkapan Imunisa- kap Pada Bayi Tahun 2015. Jurnal Kessi Dasar Di Wilayah Kerja Puskesmas $X$ ehatan Masyarakat Andalas. 123-35. Kota Kediri. Saintika Medika.12:120-28. Wati. 2015. Determinan Kepatuhan Ibu Dalam Putri, et al. 2015. Pembagian Peran Dalam Rumah Mengimunisasikan Anak Usia Sekolah Di Kota Tangga Pada Pasangan Suami Istri Jawa [The- Tangerang Tahun 2015. Universitas Indonesia. 